\title{
POPULATION DYNAMICS OF THE MULLET FISH, RHINOMUGIL CORSULA (HAMILTON, 1822), IN THE SITAKUNDA COAST OF THE BAY OF BENGAL
}

\author{
Syeda Ismat Ara, M.A. Azadi ${ }^{1}$, Munira Nasiruddin, \\ Aftab Hossain and M.G. Mustafa ${ }^{2}$ \\ Department of Zoology, University of Chittagong, \\ Chittagong-4331, Bangladesh
}

\begin{abstract}
Population dynamics of the mullet species, Rhinomugil corsula, was studied, using FiSAT-II program, with the length-frequency data of 2480 fish specimens. The asymptotic length $\left(\mathrm{L}_{\infty}\right)$ and growth coefficient $(\mathrm{K})$ of this fish were estimated to be $31.4 \mathrm{~cm}$ and 1.0/year, respectively. The instantaneous rate of natural mortality $(\mathrm{M})$, fishing mortality $(\mathrm{F})$ and total mortality $(\mathrm{Z})$ were estimated to be $1.73,1.20$ and 2.93 , respectively. The recruitment pattern of the species was prolonged with two peaks, major peak during June to December and a minor peak during January to April. The $\mathrm{L}_{25}, \mathrm{~L}_{50}$ and $\mathrm{L}_{75}$ were found to be $8.61,10.42$ and $12.23 \mathrm{~cm}$, respectively. The relative yield per recruit $\left(\mathrm{Y}^{\prime} / \mathrm{R}\right)$ and biomass per recruit $\left(\mathrm{B}^{\prime} / \mathrm{R}\right)$ were 0.751 and 1.731 , respectively. The value of exploitation $(\mathrm{E})$ was found to be 0.41 which indicated that $R$. corsula was not over fished $(\mathrm{E}>0.50)$ in the study area. The maximum exploitation $\left(\mathrm{E}_{\max }\right)$ value was 0.55 . The growth performance index $\left(\phi^{\prime}=2.99\right)$ of $R$. corsula in the Sitakunda coast of the Bay of Bengal was found to be moderate.
\end{abstract}

Key words: Mullet fish, Rhinomugil corsula, population dynamics, Bay of Bengal, Sitakunda coast

\section{INTRODUCTION}

Mugilid fish, Rhinomugil corsula, locally known as 'Bata, Khorsula or Khalla', is a popular mullet species inhabiting the freshwater rivers as well as coastal and estuarine brackish water of Southern Asia, especially in Bangladesh, India, Nepal and Myanmar (Rahman 2005). It can tolerate wide ranges of environmental fluctuations and found in freshwater, brackish water and coastal waters at a depth range of 10 - 15 meters (Riede 2004). It is one of the most popular and commercially important fish for its high nutritive and market value (Sultana et al. 2013). Despite the high commercial and nutritional importance of this mugilid fish no major attention has yet been paid on its population dynamics in Bangladesh.

To manage a natural fish population for sustainable yield study on population dynamics is essential. Fish population dynamics is the fluctuation in number of fish in a population due to several factors such as reproduction,

*Author for correspondence: <maazadi@yahoo.com>. ${ }^{1}$ International Islamic University, Chittagong4318, Bangladesh. ${ }^{2}$ Center for Resource Development Studies Ltd., Dhaka 1207, Bangladesh.

C2019 Zoological Society of Bangladesh DOI: https://doi.org/10.3329/bjz.v47i2.44341 
growth, mortality, and recruitment (King 2007) for which a given population grows or shrinks. A fishery population is affected by three dynamic rate functions i.e., birth rate or recruitment, growth rate and mortality (King 2007). If these rates measured over different time intervals, the harvestable surplus of the fishery can be determined (King 2007).

In Bangladesh population dynamics of several fishes have been done by many authors such as Mustafa and Khan (1988), Azadi et al. (1995, 1996, 1997), Azadi and Guddus (1995), Azadi and Barua (1999), Mustafa and Azadi (1995), Azadi (2000), Azadi and Mamun (2009), and Sarkar et al. (2017). However, studies on population dynamics of mullets, especially of Rhinomugil corsula, has not been done yet in Bangladesh. Fatima (1991) studied the age growth of $R$. corsula of Yamuna River of India by scale method.

Nedreaas (1990) stated that determination of age and growth by employing direct methods, such as scale method, are perhaps the most complicated and controversial in fish biology and also very expensive, especially for tropical fish. Dutt (1969) and Gasim (1973) pointed out that the growth checks of the hard parts of the tropical fishes, though formed, do not show a yearly regular pattern; as the environmental conditions of summer and winter is not so extreme in the tropical region as it is in the temperate region.

Therefore, to overcome the collection of costly hard parts (such as otolith and other body parts) and to use the easily available length frequency data for the study of fish population dynamics, several computer based programs are made and used, such as Length-based Fish stock Assessment (LFSA) (Sparre 1987), MULTIFAN (Fournier et al. 1990) and FiSAT (Gayanilo and Pauly 1997). In the present study, the population dynamics (growth parameters, mortality, selection pattern, exploitation rate, recruitment pattern and yield) of $R$. corsula were investigated from length frequency data analysis using FiSAT II (FAO ICLARM Stock Assessment Tools) (Gayanilo et al. 1996). It is resulted from the merging of LFSA (Length based Fish Stock Assessment) developed by FAO (Sparre 1987) and the Complete ELEFAN (Electronic Length Frequency Analysis) package (Gayanilo et al. 1989).

\section{MATERIAL AND METHODS}

For this study, a total of 2480 samples of Rhinomugil corsula, ranging from 3.3 to $29.5 \mathrm{~cm}$ length and 0.4 to $235.34 \mathrm{~g}$ weight, were collected from the Sitakunda coast of Bay of Bengal monthly for two-year period (February, 2016 to January, 2018) from the fishermen, caught by enclosure net. Monthly collected 
length frequency data of two years were merged together to facilitate the calculation and analysis.

FiSAT II (Gayanilo et al. 1996) was used to find the asymptotic length ( $\left.\mathrm{L}_{\infty}\right)$, growth co-efficient (K), total mortality (Z), Fishing mortality (F), natural mortality (M), exploitation rate, recruitment pattern, selection pattern, relative yield-perrecruit and biomass-per-recruit. Length frequency data were then analysed by electronic length frequency analysis using the correct routines in FiSAT II package (Pauly and David 1981, Pauly 1984, 1986, 1987, Gayanilo et al. 1996). In this method the growth parameters, asymptotic length $\left(\mathrm{L}_{\infty}\right)$ and growth coefficient $(\mathrm{K})$ were estimated following the von Bertalanffy growth equation (von Bertalanffy 1938): $\mathrm{L}_{t}=\mathrm{L}_{\infty}\left(1-\exp ^{-\mathrm{K}(\mathrm{t}-\mathrm{t}} 0\right)$ ).

Where, $L_{t}$ is the length at age $t, L_{\infty}$ the asymptotic length, $K$ the growth coefficient and $t_{0}$ age at which fish would have had zero length. Parameters of $L_{\infty}$ and $\mathrm{K}$ were computed from the ELEFAN I. The growth performance index $(\phi)$ for $R$. corsula was computed using the following equation (Pauly and Munro 1984). $\phi^{\prime}=\log _{10} \mathrm{~K}+2 \log _{10} \mathrm{~L}_{\infty}$

Additional estimates of $\mathrm{L}_{\infty}$ and total mortality/growth constant $(\mathrm{Z} / \mathrm{K})$ were obtained through the Powell-Wetherall Plot (Wetherall 1986 as modified by Pauly 1986). These initial estimates were fed into ELEFAN I in order to the optimized values for $L_{\infty}$ and $K$. The most optimized $L_{\infty}$ and $K$ values were obtained by ELEFAN I automatic search routine and the restructured length frequency histograms were also obtained.

The total mortality coefficient $(Z)$ was estimated using the length converted catch curve analysis in the FiSAT II program using the input parameters $\mathrm{L}_{\infty}, \mathrm{K}$ and $\mathrm{t}^{\circ} \mathrm{C}$ (Pauly 1984). The theoretical equation used in this analysis is, In $\left(\mathrm{N}_{\mathrm{i}} / \Delta \mathrm{t}_{\mathrm{i}}\right)=\mathrm{a}+\mathrm{b} \times \mathrm{t}_{\mathrm{i}}$

where, $\mathrm{N}_{\mathrm{i}}=$ The number of fish in length class $\mathrm{i}, \Delta \mathrm{t}_{\mathrm{i}}=$ The time needed for the fish to grow through length class $i, t_{i}=$ The age corresponding to the mid length of class $i$, and $b=$ The estimate of $Z$ (with sign changed).

The natural mortality (M) was estimated using the empirical relationship derived by Pauly (1980) where the mean annual temperature (T) was set at $27^{\circ} \mathrm{C}$.

$\ln \mathrm{M}=-0.0152-0.279 \ln \mathrm{L}_{\infty}+0.06543 \ln \mathrm{K}+0.463 \ln \mathrm{T}$

where, $\mathrm{M}$ is the natural mortality, $\mathrm{L}_{\infty}$ is in $\mathrm{cm}, \mathrm{K}$ is annual and $\mathrm{T}$ is the mean annual temperature (in ${ }^{\circ} \mathrm{C}$ ). Fishing mortality (F) was calculated using the formula, $\mathrm{F}=\mathrm{Z}-\mathrm{M}$.

Probability of capture can be estimated by backward projection of the number that would be expected if no selectivity had taken place.

Equation: $\mathrm{N}_{\mathrm{i}-1}=\mathrm{N}_{\mathrm{i}}^{\prime} \times \operatorname{EXP}\left(\mathrm{Z} \Delta \mathrm{t}_{\mathrm{i}}\right)$.

Where, $\mathrm{N}_{\mathrm{i}}=$ Terminal population, $\mathrm{N}^{\prime}=$ Number of fish under the length groups that not recruited under gear, $\Delta t_{i}=$ The time needed for the fish to grow 
through length class $\mathrm{i}, Z=\left(Z_{\mathrm{i}}+Z_{\mathrm{i}+1}\right) / 2, Z_{\mathrm{i}}=\mathrm{M}+\mathrm{F}_{\mathrm{i}}, \mathrm{F}_{\mathrm{i}-1}=\mathrm{F}_{\mathrm{i}}-\mathrm{X}, \mathrm{X}=\mathrm{F} /$ (No. of classes below $\left.\mathrm{P}_{1}+1\right)$, and $\mathrm{P}=$ The first length group with a probability of capture equal to 1.0 and whose lower limit is an estimate of $\mathrm{L}^{\prime}$.

The extrapolation points will be used to approximate the probability of capture.

The recruitment pattern was derived using the program of Gyanilo et al. (1989).

The exploitation ratio, $E$ was estimated as: $E=F / Z=F /(F+M)$. Length at first capture $\left(\mathrm{L}_{\mathrm{c}}\right.$ or $\left.\mathrm{L}_{50}\right)$ was estimated following Pauly (1984).

The probabilities of capture by length (Pauly 1984) were estimated by calculating the ration between the points of extrapolated descending arm and the corresponding ascending arm of the length converted catch curve. Relative yield-per-recruit $(Y / R)$ and biomass-per-recruit $(B / R)$ were obtained from the estimated growth parameters and probabilities of capture by length (Pauly and Soriano 1986). The relative yield per recruit $\left(\mathrm{Y}^{\prime} / \mathrm{R}\right)$ was predicted by considering $Y^{\prime} / R$ as a function of $U, E$ and $M / K$ by employing Beverton and Holt $Y^{\prime} / R$ analysis (knife edge) in the FiSAT II package. The relative yield per recruit equation which gives a quantity proportional to $\mathrm{Y}^{\prime} / \mathrm{R}$ was derived from the method of Beverton and Holt $(1956,1957,1966)$ through a number of algebraic manipulations. The predicted values were obtained by substituting the input parameters of $\mathrm{Lc} / \mathrm{L} \infty$ (Lc is the minimum length captured; obtained from the extrapolation of length converted catch curve) and M/K in the FiSAT II package, and according to the model.

\section{RESULTS AND DISCUSSION}

Asymptotic length $\left(L_{\infty}\right)$ and growth coefficient $(K)$ : The growth parameters asymptotic length or $\mathrm{L}_{\infty}$ and growth coefficient or $\mathrm{K}$ of von Bertalanffy growth formula was estimated to be $31.4 \mathrm{~cm}$ and 1.0/year, respectively (Fig. 1). The estimated (through ELEFAN-I) correlation co-efficient (R²) (ESP/ASP) was 0.171. The computed growth curves produced for $R$. corsula with those parameters are shown over its restructured length distribution in Fig. 1. The corresponding estimates of $L_{\infty}$ and $Z / K$ for this fish were 31.99 and 3.714, respectively using Powell-Wetherall Plot (Fig. 2). For regression, the $\mathrm{r}^{2}$ was 0.99, a and $\mathrm{b}$ values were 6.79 and -0.212 respectively. This additional estimate of $L_{\infty}$ was found to be slightly higher than the $\mathrm{L}_{\infty}$ estimated by ELEFAN I. The growth performance index $\left(\phi^{\prime}=2.99\right)$ of $R$. corsula in the Sitakunda coast of the Bay of Bengal was found to be moderate.

No study on the VBGF growth parameters of $R$. corsula, based on ELEFAN, was found. But Fatima (1991) determined the VBGF growth parameters of 
$R$. corsula by scale method and estimated asymptotic length $\left(\mathrm{L}_{\infty}\right)$ as $33.125 \mathrm{~cm}$ and growth coefficient $(\mathrm{K})$ as $0.5547 /$ year. The asymptotic length $(33.125 \mathrm{~cm})$ recorded by Fatima (1991) was found to be a little bit higher than that of the present study $(31.40 \mathrm{~cm})$, however the $\mathrm{K}$ value was far less than that of the present study. For other mugil species like Mugil cephalus, Murugan et al. (2014) recorded $\mathrm{L}_{\infty}$ as $51 \mathrm{~cm}$ (male) and $57 \mathrm{~cm}$ (female), and $\mathrm{K}$ values as 0.096/year (male) and 0.082/year (female) from Southern coast of India. For two different Mugil species of Egyptian water, Liza carinata and L. aurata, $\mathrm{L}_{\infty}$ values were estimated to be 23.51 and $32.4 \mathrm{~cm}$, respectively; whereas $\mathrm{K}$ values were 0.6 year $^{-1}$ and 0.63 /year, respectively (Mehanna 2004). Relatively high $\mathrm{K}$ and low $\mathrm{L}_{\infty}$ values, typical of short-lived tropical fishes, was obtained for $R$. corsula. In this regard the studied fish ( $R$. corsula) was a small sized fish (max. length $31.4 \mathrm{~cm}$ ) thus $\mathrm{K}$ value (1.0/year) fitted well.

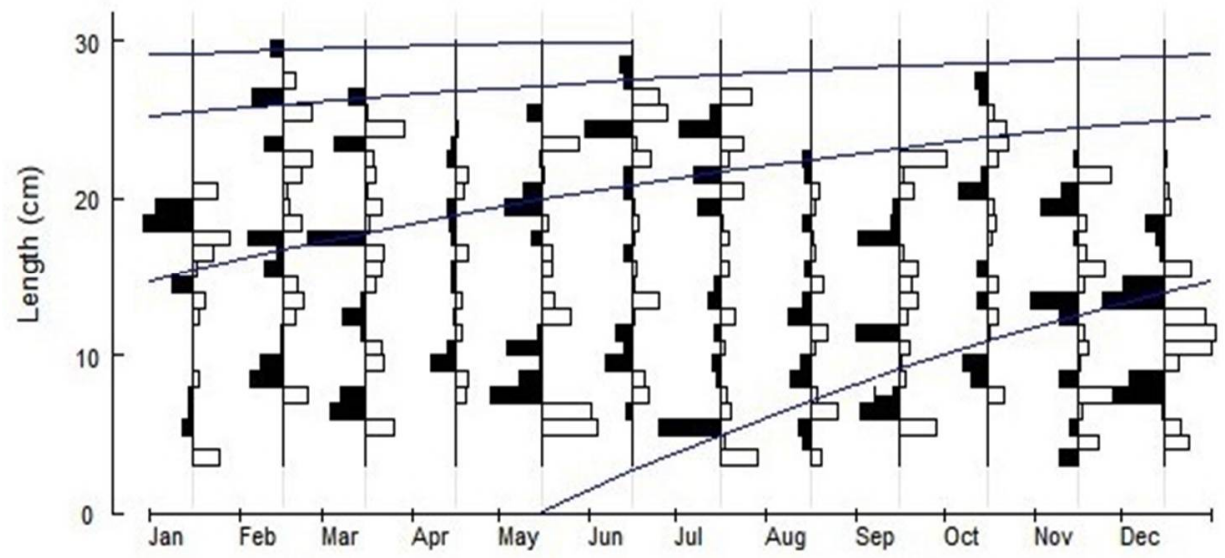

Fig. 1. Restructured length frequency histogram for R. corsula of the Sitakunda coast. $\mathrm{L}_{\infty}=31.4 \mathrm{~cm}$, growth co-efficient $(\mathrm{K})=1.0, \mathrm{R}^{2}=0.171$, peak spawning during May, $\mathrm{SS}=7, \mathrm{SL}=5.0 \mathrm{~cm}$, May, Age $3^{+}$years.

Mortality: Natural mortality (M), fishing mortality (F) and total mortality (Z) were estimated to be $1.73,1.20$ and 2.93 , respectively for $R$. corsula. Fig. 3 shows the length converted catch curve utilized in the estimation of $Z$. The dark circles represent the points used in calculating $Z$ through least square linear regression. The blank circles represent points either not fully recruited or nearing to $\mathrm{L}_{\infty}$ hence discarded from calculation. Good fit to the descending right hand limits of the catch curve was considered. For regression, the $\mathrm{r}^{2}$ was 0.995 , a and $\mathrm{b}$ values were 8.815 and -2.934 , respectively (Fig. 3). In mugil species, $L$. carinata the M, F and $Z$ values were found to be $0.96,3.24$ and 4.2 and in $L$. aurata 0.96, 1.95 and 2.91, respectively; whereas the $\mathrm{M}, \mathrm{F}$ and $Z$ values in $L$. ramada were recorded as 0.16, 1.06 and 1.22, respectively from Egypt (Mehanna 
2006). In $M$. cephalus from northarn Siani of Egypt $M, F$ and $Z$ values were recorded as 0.66, 1.07 and 1.73, respectively (Mehanna and Hegazi 2013). All the estimated $\mathrm{M}, \mathrm{F}$, and $Z$ values were recorded for different mugil species, so comparison was not possible. However, in the present study natural mortality was found to be a little bit higher than that of the fishing mortality, which disagreed with the findings of different Egyptian mugil species where fishing mortality was always higher than the natural mortality. It might be due to under fishing or sustainable fishing $(\mathrm{E}=0.41)$ in case of $M$. corsula in the coastal water of Bangladesh and over fishing in case of different mugil species in Egyptian waters. It indicated that $R$. corsula might not be overfished in the Sitakunda coast of the Bay of Bengal but the above mentioned mugil species from Egyptian waters might be overfished.

POWELL - WETHERALL PLOT

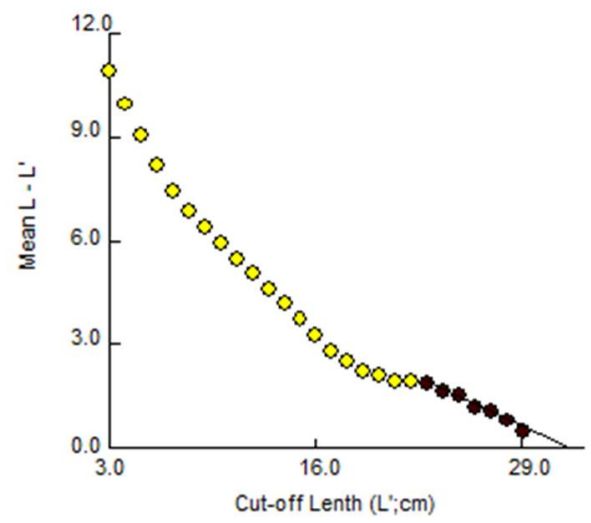

Fig. 2. Estimation of $\mathrm{L}_{\infty}$ and $\mathrm{Z} / \mathrm{K}$ using the method of Powell-Wetherall $\left(\mathrm{R}^{2}=0.99, \mathrm{a}=\right.$ $6.79, b=-0.212)$.

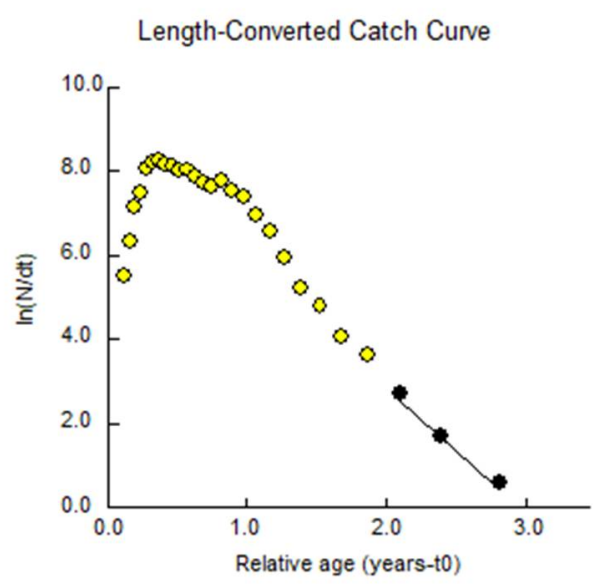

Fig. 3. Length converted catch curve of $R$. corsula for all length groups. $Z=2.93, M=1.73, F$ $=1.20$ and $\mathrm{E}=0.41$.

Selection pattern/probability of capture: From selection pattern, $\mathrm{L}_{25}, \mathrm{~L}_{50}$ and $\mathrm{L}_{75}$ were found to be $8.61,10.42$ and $12.23 \mathrm{~cm}$, respectively (Fig. 4). The length at first capture $\left(\mathrm{L}_{\mathrm{c}}\right)$ was found to be $10.42 \mathrm{~cm}$, which was reasonable harvestable size for this fish in the study area. $\mathrm{L}_{\mathrm{c}}$ values of $L$. carinata and $L$. aurata (in two different mugil species) from Egyptian waters were found to be 13.6 and 18.28 $\mathrm{cm}$, respectively (Mehanna 2004). The $\mathrm{L}_{\mathrm{c}}$ values in different mugil species from different parts of Egypt were found to be $18.45 \mathrm{~cm}$ for $L$ ramada (Mehanna 2006) and $28 \mathrm{~cm}$ for M. cephalus (Mehanna and Hegazi 2013). As no works on $R$. corsula was found so comparison was not possible.

Recruitment pattern: Through the ELEFAN II analysis (Pauly and David 1981), with the separation of the normal distribution of the peaks by means of the NORMSEP program the recruitment pattern was determined which showed 
two recruitment peaks (Fig. 5). The major peak occurred during June to December, whereas the minor or lean peak occurs during January to April (Fig. 5). Mehanna (2004) found one recruitment pulse for $L$. aurata and $L$. carinata in

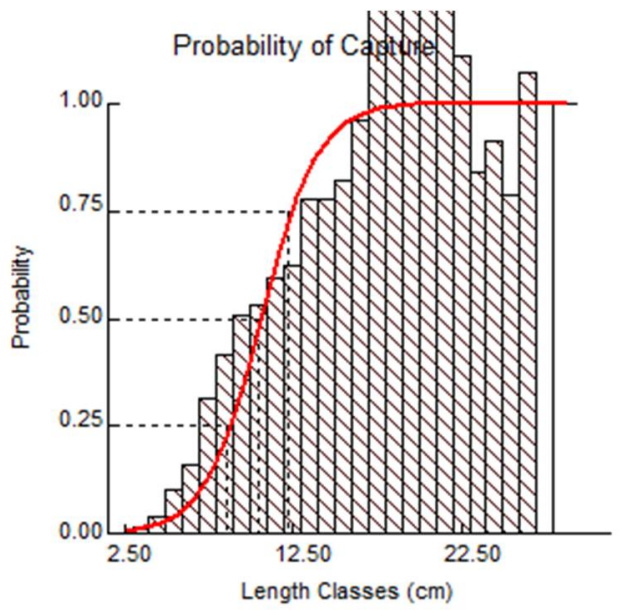

Fig. 4. Selection pattern (probability of capture) of $R$. corsula produced through length converted catch curve module. Selection patterns were $\mathrm{L}_{25}=8.61 \mathrm{~cm}, \mathrm{~L}_{50}=10.42 \mathrm{~cm}$, $\mathrm{L}_{75}=12.23 \mathrm{~m}$.

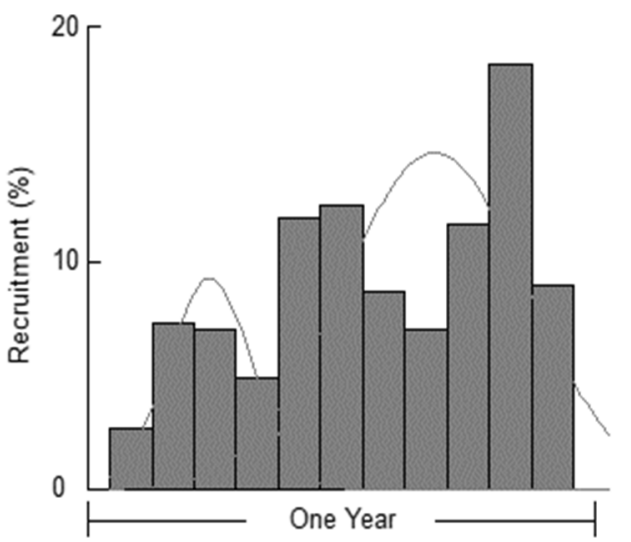

Fig. 5. Recruitment pattern of $R$. corsula produced through recruitment pattern module of FiSAT II program.

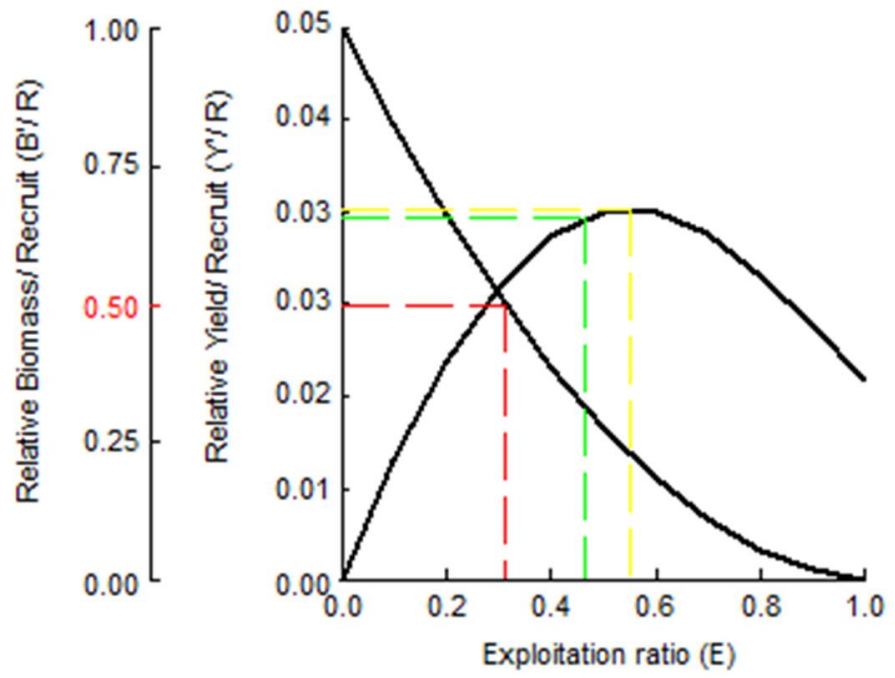

Fig. 6. Exploitation ratio of $R$. corsula showing biomass per recruit $\left(\mathrm{B}^{\prime} / \mathrm{R}\right)$ and yield per recruit $\left(\mathrm{Y}^{\prime} / \mathrm{R}\right)$ produced through the knife edge selection of Beverton and Holt Y/R analysis module of FiSAT II program.

Egyptian waters. This pattern agrees with the findings of Fatema (1991) as she pointed out this fish as a prolonged breeder; but disagrees with the findings of Mehanna (2004) for different species of mugils in Egypt. 
Exploitation ratio: The relative yield-per-recruit and biomass-per-recruit were determined as a function of $\mathrm{Lc} / \mathrm{L}_{\infty}$ and $\mathrm{M} / \mathrm{K}$, which were 0.751 and 1.731, respectively. The $\mathrm{E}_{10}$ and $\mathrm{E}_{50}$ and $\mathrm{E}$-max were found to be $0.462,0.321$ and 0.55, respectively (Fig. 6) which showed that the present exploitation rate, $\mathrm{E}=$ 0.41 which does not exceed the E-max (0.55), indicated the fish was not over fished in the Sitakunda coast of Bay of Bengal as Gulland (1971) stated that E value above 0.5 indicates over fishing of a species in an area.

\section{LITERATURE CITED}

AZADI, M.A. 2000. Population dynamics of two major carps Labeo rohita (Ham.) and Catla catla (Ham.) in Kaptai Reservior, Bangladesh. Paper presented in the $130^{\text {th }}$ Annual Meeting of the American Fisheries Society, 20-24 August, 2000, St Louis, Missouri, AFS Reflection Abstract Book, pp. 78-79.

AZADI, M.A. and BARUA, R.K. 1999. Population biology and fishery of the Clupeid, Corica soborna (Hamilton) in Kaptai Reservior, Bangladesh. Contribuited poster presented at the 129th Annual Meeting of the American Fisheries Society, August 29-September 2, 1999, Charlotte, North Carolina. Abstract No. 179, pp. 70-71.

AZADI, M.A. and QUDDUS, M.A. 1995. Age and Growth of a carp, Labeo calbasu (Hamilton) from Kaptai Reservoir, Bangadesh. Chittagong Univ. Stud. Part II: Sci. 19(1): 7-17.

AZADI, M.A. and MAMUN, A. 2009. Population dynamics of the Cyprinid fish Amblypharyngodon mola (Ham.) from the Kaptai Lake, Bangladesh. Chittagong Univ. J. Biol. Sci. 4(1\&2): 141-151.

AZADI, M.A., MUSTAFA, M.G. and ISLAM, M.S. 1995. ELEFAN based population dynamics of Parapenaepsis sculptilis (Heller) from Kumira estuary, Chittagong, Bangladesh. Chittagong Univ. Stud. Part-II: Sci. 19(2): 181-190.

AZADI, M.A., MUSTAFA, M.G. and NASER, A. 1996. Studies on some aspects of population dynamics of Labeo bata from Kaptai reservior, Bangladesh. Chittagong Univ. Stud. Part II: Sci. 20(1):13-18.

AZADI, M.A., MUSTAFA, M.G. and RAHMAN, A.S.M. S. 1997. ELEFAN based population dynamics of two clupeids Gudusia chapra (Ham.) and Gonialosa manmina (Ham) from Kaptai Reservior, Bangladesh. Chittagong Univ. Stud. Part II: Sci. 21(2): 125-132.

BEVERTON, R.J.H. and HOLT, S.J. 1956. A review of methods for estimating mortality rates infish populations with special references to sources of bias in catch sampling. Rapp. P-V. Renn. Cons. Int. Explor. Mer. 140: 67-83.

BEVERTON, R.J.H. AND HOLT, S.J. 1957. On the Dynamics of Exploited Fish Populations. Gt Britain Fish Invest. Ser. 2, 19: 1-533.

BEVERTON, R.J.H. and HOLT, S.J. 1966. Manual of Methods for Fish Stock Assessment, Part 2. In: Tables of Yield Functions, Fisheries Technical Paper No. 38. Food and Agriculture Organization of the United Nations, Rome, Italy, pp. 7-29.

DUTT, S. 1969. Studies on age and growth of the cat fish Osteogeneiosus militaris (Linn.). J. Cons. Int. Explor. Mer. 33: 109-110.

FATIMA, M. 1991. Studies on the biology of a grey mullet, Rhinomugil corsula (Hamilton), collected from River Yamuna. PhD thesis, Department of Zoology, Aligarh Muslim University, Aligarh, India, pp. 198. 
FOURNIER, D.A., SIBERT, J.R., MAJKOWSKI, J. and HAMPTON, J. 1990. MULTIFAN - a likelihoodbased method for estimating growth parameters and age composition data sets illustrated by using data for Southern blue fin tuna (Thunnu smaccoyii). Can. J. Fish. Aquat. Sci. 47 (2): $301-$ 317.

GAYANILO, F.C. and PAULY, D. 1997. The FAO ICLARM Stock Assessment Tools (FiSAT): Reference Manual. Food and Agriculture Organization of the United Nations, Rome, Italy. pp.15-42

GAYANILO, Jr. F.C., SORIANO, M. and PAULY, D. 1989. A draft guide to the complete ELEFAN. ICLARM Software 2, 70 pp.

GAYANILO, Jr. F.C., SPARRE, P. and PAULY, D. 1996. FAO-ICLARM Stock Assesment Tools (FISAT). User's Manual. (Computerized Information Series Fisheries No. 8). Food and Agriculture Organization of the United Nations, Rome, p. 126

GULLAND. J.A. 1971. The Fish Resources of the Oceans, Fishing News, London, 1971, p. 9-52.

KING, M. 2007. Fisheries biology, assessment and management. Fishing News Book, London, pp. 342

MEHANNA, S.F. 2006. Fisheries management of the thinlip grey mullet Liza ramadaand golden grey mullet Liza auratafrom lake Bardawil, Egypt. Egypt. J. Aquat. Fish. 10(2): 33-53.

MEHANNA, S.F. and HEGAZI, M.M. 2013. Population dynamics of grey mullet Mugilcephalus associated with seagrass community in Bardawil lagoon, Northern Sinai, Egypt. INOC-XIII International Symposium 2013, Malaysia.

MEHANNA. S.F. 2004. Population dynamics of keeled mullet Liza carinataand golden grey mullet Liza aurataat the Bitter Lakes, Egypt. Egyp. J. Aquat. Res. 30(B): 315-321.

MURUGAN, S., ASHIQ- UR- RAHMAN, M., KHAN, A.S. and LYLA, P.S. 2014. Growth and Population dynamics of Flathead grey mullet, Mugil cephalus (Linnaeus, 1758) from Parangipettai waters (Southeast coast of India). Thalassas 30(2): 47-56.

MUSTAFA, M.G. and AZADI, M.A. 1995. Population dynamics of white grunter Pomadasys hasta from the Bay of Bengal. Chittagong Univ. Stud. Part II: Sci. 19(1):19-22.

MUSTAFA, M.G. and KHAN, M.G. 1988. Studies on some aspects of the population dynamics of Lizard fish Saurida tumbil Bloch from the Bay of Bengal. Bangladesh J. Zool. 16(2): 77 - 84.

NEDREAAS, K .1990. Age determination of northeast Atlantic Sebastes species. J. Cons. Int. Explor. Mer. 47: 208-230.

PAULY, D. 1980. On the inter-relationship between natural mortality, growth parameters and mean environmental temperature in 175 fish stocks. Journal du Conseil 39(3): 175-192.

PAULY, D. and MUNRO, J.L. 1984. Once more on the comparison of growth in fish and invertebrates. Fishbyte 2(1): 1-21.

PAULY, D. 1984. Fish population dynamics in tropical waters: A manual for use with programmable calculators. ICLARM Stud. Rev. 8: 325.

PAULY, D. 1986. On improving operation and use of the ELEFAN programme. Part II. Improving the estimation of $\mathrm{L}_{\infty}$. Fishbyte 4(1): 18-20.

PAULY, D. 1987. A review of the ELEFAN systems for analysis of length-frequency data in fish and aquatic vertebrates, p. 7-34. In Pauly, D. Morgan, G.R. (eds.). Length-based methods in fesheries research. ICLARM Conference Procedings 13.

PAULY, D. and DAVID, N. 1981. ELEFAN I BASIC Programme for the objective extraction of growth parameters from Length frequency data. Meeresforsch 28(4): 205-211.

PAULY, D. and SORIANO, M.L. 1986. Some practical extensions to Beverton and Holt's relative yield per-recruit model, In: First Asian Fisheries Forum (eds. J.L. Maclean, L.B. Dizon and L.V. Hosillos), Asian Fisheries Society, Manila, Philippines. pp. 149-495. 
QASIM, S.Z. 1973. Some implications of the problem of age and growth in marine fishes from the Indian waters. Indian J. Fish. 20 (2): 351-371.

RAHMAN, A.K.A. 2005. Freshwater Fishes of Bangladesh. The Zoological Society of Bangladesh, Dhaka. pp. 394.

RIEDE, K. 2004. Global register of migratory species - from global to regional scales. Final Report of the R\&D Project 80805 081. Federal Agency for Nature Conservation, Bonn, Germany, pp. 329.

SARKER, M.N., HUMAYUN, M., RAHMAN, A.M. and UDDIN, M.S. 2017. Population Dynamics of Bomay Duck, Harpodon neherius (Hamilton, 1822) of the Bay of Bengal along Bangladesh coast. Bangladesh J. Zool. 45(2): 101-110.

SPARRE, P. 1987. Computer programs for fish stock assessment. Length-based fish stock assessment for Apple II computers. FAO Fish. Tech. Pap. 101. Suppl. 2, pp. 218.

SULTANA, S., SHAH, M.S., ISLAM, S.S. and GHOS, A.K. 2013. Taxonomy and other biological aspect of Rhinomugil corsula (Hamilton). International Journal of Research in Biological Science 3(3): 123131.

VON BERTALANFFY, L. 1938. A quantitative theory of organic growth (Inquiries on growth laws. 2). Hum. Biol. 10: 181-213.

WETHERALL, J.A. 1986. A new method for estimating growth and mortality parameters from length frequency data. Fishbyte 4(1): 12-15.

(Manuscript received on 21 October, 2019; revised on 8 November, 2019) 